\title{
PERBANDINGAN MORFOMETRIK KUDA DI KECAMATAN TOMPASO BARAT DAN DI NUSANTARA POLO CLUB BOGOR JAWA BARAT
}

\author{
Grantino F. Turangan, Umar Paputungan*, Zulkifli Poli, Agustinus Lomboan.
}

Fakultas Peternakan, Universitas Sam Ratulangi Manado. 95115.

\begin{abstract}
ABSTRAK
Penelitian ini bertujuan untuk melihat adanya perbandingan morfometrik dan sebagai bahan informasi dalam usaha peningkatan kualitas ternak kuda. Jumlah kuda yang diteliti sebanyak 44 ekor kuda. Penelitian ini telah dilaksanakan di Kecamatan Tompaso Barat dan di Nusantara Polo Club Bogor Jawa Barat dan penelitian dilaksanakan pada bulan November 2016 - Januari 2017. Menggunakan metode purposive sampling dimana penentuan daerah dilakukan secara teratur berdasarkan pertimbangan jumlah populasi kuda terbesar kemudian dilanjutkan dengan pengukuran morfometrik secara acak. Empat puluh empat ekor kuda yang diukur dan diamati dengan hati-hati untuk menghindari kuda yang tidak sehat dan bunting. Kuda bunting dihindari karena efeknya berpengaruh pada beberapa pengukuran tubuh terutama ukuran dada. Sepuluh ukuran tubuh yang diambil yaitu lingkar dada, lebar dada, dalam dada, tinggi pundak, tinggi pinggul, lebar pinggul, panjang badan, panjang leher, lebar kepala, panjang kepala. Hasil pengamatan dan analisa perbandingan morfometrik tubuh kuda di Kecamatan Tompaso Barat dan di Nusantara Polo Club Bogor Jawa Barat maka dapat di simpulkan bahwa terdapat tujuh perbedaan dari anggota-anggota tubuh yang di ukur seperti, lingkar dada, tinggi pundak, lebar pinggul, panjang badan, panjang leher, lebar kepala, dan panjang kepala.
\end{abstract}

Kata kunci : Morfometrik, kuda

*Korespondensi (corresponding author) Email: umarfapet@yahoo.com

\section{ABSTRACT}

This study was done to evaluate the phenotypic comparison of the body measurements for genetic improvement of running horses at West Tompaso district and those at Nusantara Polo Club Bogor West Java.. Total of forty four running horses consisted of twenty two horses from Nusantara Polo Club Bogor and twenty two horses from West Tompaso district were used in this study. Observation was conducted on November 2016 - January 2017 using purposive sampling method to measure body size of horses. The pregnant horses were excluded in this. The variables measured in this study were including chest girth, chest wide, chest depth, shoulder height, hip height, hip wide, body length, neck length, head wide, and head length. Results showed that body measurements of horses at West Tompaso district tended bigger in the sizes of hip wide, head wide and head length compared with those of horses at Nusantara Polo Club Bogor West Java. While, the body measurements of horses at Nusantara Polo Club Bogor West Java tended bigger in the sizes of chest girth, shoulder height, body length and neck length compared with those at West Tompaso district.

Key words: Morfometrik, horse

\section{PENDAHULUAN}

Kuda merupakan salah satu binatang peliharaan yang banyak dipilih orang pada zaman dahulu, karena 
kemampuannya yang sangat beragam dan memiliki fungsi yang sangat besar. Kuda juga bisa menggambarkan bagaimana profil dari sang penunggang, dimana dengan tunggangan yang gagah tentunya akan menambah gagah juga sang penunggang yang rata-rata merupakan para ksatria dan prajurit pada masa lalu.

Hubungan kuda dengan manusia sangat erat kaitannya seperti peranan kuda sebagai transportasi dan pengangkut beban bahkan dibeberapa tempat digunakan sebagai sumber protein hewani, selain itu kuda dapat dimanfaatkan sebagai kuda perang, kuda rekreasi, kuda olahraga. Seiring perkembangan kuda memiliki daya tarik tersendiri bagi penggemarnya, diantaranya digunakan pada berbagai macam pertandingan olahraga berkuda yaitu polo sport, pacuan kuda, show jumping, dan masih banyak lagi jenis pertandingan olahraga lainnya yang menggunakan kuda.

Kuda Pacu asal Tompaso Barat terkenal sejak lama dikalangan penggemar pacuan kuda dan menjuarai banyak lomba. Kecamatan Tompaso Barat Kabupaten Minahasa, Sulawesi Utara memiliki udara yang dingin. Tompaso juga salah satu kawasan lain di Indonesia timur yang sudah lama terkenal dengan kuda pacunya. Menurut catatan, sudah sejak 1950-an warga Tompaso terkenal suka memelihara kuda dan biasanya mereka berpacu di
Pacuan Maesa Tompaso. Kuda asli Tompaso berukuran tinggi 140 sentimeter. Ukuran itu sebelum terjadi persilangan dengan kuda luar yang terkenal bertubuh tinggi. Baru setelah datang kuda-kuda jantan dari Australia, yang dikenal dengan Thoroughbred (kuda keturunan murni) maka terjadi perkawinan antara kuda Tompaso dan Australia.

Nusantara Polo Club adalah klub polo berkuda eksklusif pertama di Indonesia yang dibangun oleh Prabowo Subianto di kawasan Jagorawi Golf \& Country Club. Nusantara Polo Club membina tim nasional polo Indonesia, kuda poni polo bukan suatu bangsa (atau bukan lagi kuda poni), melainkan adalah tipe khusus yang dikembangkan dan dikenali berdasarkan garis besar dan penampilan umumnya. Awalnya, dibuat batas ketinggian yang ditetapkan berdasarkan aturan main polo, namun ditiadakan setelah perang dunia I. Bangsa Argentina mendominasi permainan dan memiliki fasilitas untuk menghasilkan sejumlah kuda berkualitas. Bangsa Argentina mengimpor Thoroughbred kemudian menyilangkannya dengan kuda peranakan Criollo, untuk mendapatkan kuda yang tangguh dan memiliki kecepatan yang baik.

Kecepatan lari pada kuda dihasilkan oleh perpaduan antara panjang langkah dan frekuensi melangkah. Tinggi pundak berhubungan dengan kecepatan lari, 
semakin tinggi pundak makin baik sehingga mempunyai daya mobilitas dan daya tahan (endurance) yang tinggi.

Karakter morfometrik dapat dijadikan faktor pembeda setiap mahluk hidup. Sebagai penduga yang mewakili bentuk dan deskripsi khas dari bentuk tubuh, maka karakter morfometrik sangat bermanfaat dalam menganalisa karakteristik banyak mahluk hidup, pengukuran panjang tulang-tulang mempunyai ketelitian yang lebih baik dibandingkan dengan pengukuran bobot badan, dan menambahkan untuk ukuranukuran tubuh yang memiliki keragaman tinggi dapat memberikan petunjuk bahwa ukuran-ukuran tersebut dapat dijadikan kriteria untuk seleksi dalam upaya peningkatan kualitas.

\section{MATERI DAN METODE PENELITIAN}

Penelitian ini telah dilaksanakan di Kecamatan Tompaso Barat dan di Nusantara Polo Club Bogor Jawa Barat dan penelitian dilaksanakan pada bulan November 2016 - Januari 2017. Materi penelitian yang digunakan dalam penelitian ini adalah kuda yang ada di Kecamatan Tompaso Barat dan kuda yang ada di Nusantara Polo Club Bogor Jawa Barat. Kuda yang dijadikan sampel adalah kuda dewasa. Sepuluh ukuran tubuh diambil dari
9 ekor kuda jantan, 13 ekor kuda betina di Kecamatan Tompaso Barat dan 9 ekor kuda Jantan, 13 ekor kuda betina di Nusantara Polo Club Bogor Jawa Barat.

Empat puluh empat ekor kuda yang diukur dan diamati dengan hati-hati untuk menghindari kuda yang tidak sehat dan bunting. Kuda bunting di hindari karena efeknya berpengaruh pada beberapa pengukuran tubuh terutama ukuran dada.

Variabel yang diamati adalah lingkar dada, lebar dada, dalam dada, tinggi pundak, tinggi pinggul, lebar pinggul, panjang badan, panjang leher, lebar kepala, dan panjang kepala. Data yang terkumpul dianalisis secara statistik deskriptif yaitu dengan tabulasi, rata-rata sampel, presentase, standar deviasi, koefisien keragaman dan uji t.

\section{HASIL DAN PEMBAHASAN}

\section{Lingkar Dada}

Hasil pengukuran kuda di Kecamatan Tompaso Barat memiliki lingkar dada ratarata $167,909 \pm 5,813 \mathrm{~cm}$ dengan Koefisien keragaman $3,41 \%$ dan rata-rata lingkar dada kuda di Nusantara Polo Club Bogor Jawa barat 177,636 \pm 7,345 $\mathrm{cm}$ dengan koefisien keragaman 4,13\% (Tabel 1). Lingkar dada rata-rata kuda di Kecamatan Tompaso Barat di bandingkan lingkar dada rata-rata kuda di Nusantara Polo Club Bogor Jawa barat berbeda sangat nyata. 
Tabel 1. Rataan dan Varian Lingkar Dada Kuda di Kecamatan Tompaso Barat dan di Nusantara Polo Club Bogor Jawa Barat.

\begin{tabular}{lllllll}
\hline \multirow{2}{*}{ No } & Jenis kelamin & \multicolumn{2}{c}{$\begin{array}{c}\text { Kecamatan Tompaso } \\
\text { Barat }\end{array}$} & $\begin{array}{c}\text { Nusantara Polo } \\
\text { Club }\end{array}$ & \\
\cline { 3 - 6 } & & $\begin{array}{l}\text { Rata-rata }(\mathrm{Cm}) \pm \\
\text { SD }\end{array}$ & KK\% & $\begin{array}{l}\text { Rata- rata }(\mathrm{Cm}) \\
\pm \text { SD }\end{array}$ & $\begin{array}{l}\text { KK } \\
\%\end{array}$ & Uji t \\
\hline 1 & Jantan dan & $167,909 \pm 5,813$ & 3,41 & $177,636 \pm 7,345$ & 4,13 & $* *$ \\
& Betina $(\mathrm{n}=22)$ & & & & & \\
2 & Jantan $(\mathrm{n}=9)$ & $166,444 \pm 7,434$ & 4,46 & $178,333 \pm 8,062$ & 4,52 & $* *$ \\
3 & Betina $(\mathrm{n}=13)$ & $168,923 \pm 4,424$ & 2,61 & $177,154 \pm 7,104$ & 4,01 & $* *$ \\
\hline$* *)$ Berbeda sangat nyata $(\mathrm{P}<0,01) ;$ & & & & \\
$*$ *) Berbeda nyata $(\mathrm{P}<0,05)$ & & & & \\
Ns) Tidak berbeda nyata/ non signifikan $(\mathrm{P}>0,05)$ & &
\end{tabular}

Hasil pengukuran kuda di Kecamatan Tompaso Barat memiliki lingkar dada rata-rata $167,909 \pm 5,813 \mathrm{~cm}$ dengan Koefisien keragaman 3,41\% dan rata-rata lingkar dada kuda di Nusantara Polo Club Bogor Jawa barat 177,636 \pm $7,345 \mathrm{~cm}$ dengan koefisien keragaman 4,13\% (Tabel 1). Lingkar dada rata-rata kuda di Kecamatan Tompaso Barat di bandingkan lingkar dada rata-rata kuda di Nusantara Polo Club Bogor Jawa barat berbeda sangat nyata. Pada Tabel 1 lingkar dada rata-rata pada jantan maupun betina kedua daerah berbeda sangat nyata $(\mathrm{P}<$ $0,01)$.

Lingkar dada kuda yang berada di Nusantara Polo Club Bogor Jawa Barat lebih besar dari Kuda yang berada di Kecamatan Tompaso barat dikarenakan faktor genetik dan juga fungsi kedua kuda tersebut berbeda karena Kuda di Nusantara Polo Club Bogor Jawa Barat digunakan untuk Polo Sport dan dalam pertandingan tersebut terdapat 4 babak dan setiap 1 babak selama 7 menit. Sedangkan Kuda di Kecamatan Tompaso Barat digunakan sebagai Horse Racing, dalam pertandingan tersebut kuda di pacu sesuai dengan kelas kuda tersebut untuk sampai sampai pertama di garis finish.

Lingkar dada yang besar akan menjadikan besarnya ruang untuk organ pernafasan dan sistem kardiovaskular dari tubuh kuda. Besarnya ruang dari organ pernafasan membuat paru paru dapat mengembang dengan maksimal sehingga dapat menyimpan volume oksigen lebih besar (Evan, 2016).

\section{Lebar Dada}

Hasil pengukuran kuda di Kecamatan Tompaso Barat memiliki lebar dada rata-rata 36,727 $\pm 2,621 \mathrm{~cm}$ dengan koefisien keragaman 7,13\% dan rata-rata lebar dada kuda di Nusantara Polo Club Bogor Jawa Barat 36,318 $\pm 2,254 \mathrm{~cm}$ 
Tabel 2. Rataan dan Varian Lebar Dada Kuda di Kecamatan Tompaso Barat dan di Nusantara Polo Club Bogor Jawa Barat.

\begin{tabular}{lllllll}
\hline \multirow{2}{*}{ No } & Jenis kelamin & \multicolumn{2}{c}{$\begin{array}{c}\text { Kecamatan Tompaso } \\
\text { Barat }\end{array}$} & $\begin{array}{l}\text { Nusantara Polo } \\
\text { Club }\end{array}$ & & Hasil \\
\cline { 3 - 6 } & $\begin{array}{l}\text { Rata-rata }(\mathrm{Cm}) \\
\pm \mathrm{SD}\end{array}$ & KK\% & $\begin{array}{l}\text { Rata- rata }(\mathrm{Cm}) \\
\pm \text { SD }\end{array}$ & KK\% & Uji t \\
\hline 1 & $\begin{array}{l}\text { Jantan dan Betina } \\
(\mathrm{n}=22)\end{array}$ & $36,727 \pm 2,621$ & 7,13 & $36,318 \pm 2,254$ & 6,20 & $n s$ \\
2 & Jantan (n=9) & $37,333 \pm 2,291$ & 6,13 & $36,666 \pm 2,5$ & 6,81 & $n s$ \\
3 & Betina (n=13) & $36,307 \pm 2,933$ & 8,07 & $36,076 \pm 2,139$ & 5,92 & $n s$ \\
\hline
\end{tabular}

**) Berbeda sangat nyata $(\mathrm{P}<0,01)$

*) Berbeda nyata $(\mathrm{P}<0,05)$

Ns) Tidak berbeda nyata/ non signifikan $(\mathrm{P}>0,05)$

dengan koefisien keragaman 6,20\% (Tabel

2). Lebar dada rata-rata kuda di Kecamatan

Tompaso Barat di bandingkan lebar dada

rata-rata kuda di Nusantara Polo Club

Bogor Jawa barat tidak berbeda nyata. Pada

Tabel 2 lingkar dada rata-rata pada jantan maupun betina kedua daerah tidak berbeda nyata $(\mathrm{P}>0,05)$. Lebar dada kuda di Kecamatan Tompaso Barat dan di Nusantara Polo Club Bogor Jawa Barat tidak berbeda nyata ada kemungkinan ada kesamaan genetik. Kuda yang baik memiliki lebar dada yang ideal (tidak terlalu lebar dan sempit). Hal tersebut sesuai dengan pendapat Wood dan Jackson (2004) dada yang terlalu lebar menjadikan kuda sulit berjalan, tidak memiliki keseimbangan dan langkah yang tidak atletis. Dada yang terlalu sempit juga dapat menyebabkan kuda kesulitan dalam berjalan.

\section{Dalam dada}

Hasil pengukuran kuda di Kecamatan Tompaso Barat memiliki dalam dada rata-rata $42,454 \pm 4,148 \mathrm{~cm}$ dengan Koefisien keragaman 9,77\% dan rata-rata dalam dada kuda di Nusantara Polo Club Bogor Jawa barat $42,863 \pm 4,852 \mathrm{~cm}$ dengan koefisien keragaman 11,31\% (Tabel 3). dalam dada rata-rata kuda di Kecamatan Tompaso Barat di bandingkan dalam dada rata-rata kuda di Nusantara Polo Club Bogor Jawa barat tidak berbeda nyata. Pada Tabel 3 dalam dada rata-rata pada jantan maupun betina kedua daerah tidak berbeda nyata $(\mathrm{P}>0,05)$.

Dalam dada kuda di Kecamatan Tompaso Barat dan di Nusantara Polo Club Bogor Jawa Barat tidak berbeda nyata kemungkinan ada kesamaan genetik. Fourie et al. (2002) menyatakan bentuk dan ukuran tubuh dapat ditentukan dengan cara mengukur langsung ataupun secara visual. 
Tabel 3. Rataan dan Varian Dalam Dada Kuda di Kecamatan Tompaso Barat dan di Nusantara Polo Club Bogor Jawa Barat.

\begin{tabular}{|c|c|c|c|c|c|c|}
\hline \multirow[t]{2}{*}{ No } & \multirow[t]{2}{*}{ Jenis kelamin } & \multicolumn{2}{|c|}{$\begin{array}{c}\text { Kecamatan Tompaso } \\
\text { Barat }\end{array}$} & \multicolumn{2}{|l|}{$\begin{array}{c}\text { Nusantara Polo } \\
\text { Club }\end{array}$} & \multirow{2}{*}{$\begin{array}{l}\text { Hasil } \\
\text { Uji t }\end{array}$} \\
\hline & & $\begin{array}{l}\text { Rata-rata } \\
(\mathrm{Cm}) \pm \mathrm{SD}\end{array}$ & $\mathrm{KK} \%$ & $\begin{array}{l}\text { Rata- rata } \\
(\mathrm{Cm}) \pm \mathrm{SD}\end{array}$ & $\mathrm{KK} \%$ & \\
\hline 1 & $\begin{array}{l}\text { Jantan dan } \\
\text { Betina }(n=22)\end{array}$ & $42,454 \pm 4,148$ & 9,77 & $42,863 \pm 4,852$ & 11,32 & $n s$ \\
\hline 2 & Jantan $(\mathrm{n}=9)$ & $43,777 \pm 4,630$ & 10,57 & $43,111 \pm 5,644$ & 13,09 & $n s$ \\
\hline 3 & Betina $(n=13)$ & $41,538 \pm 3,688$ & 8,87 & $42,692 \pm 4,460$ & 10,45 & $n s$ \\
\hline
\end{tabular}

Hasil pengukuran kuda di Kecamatan Tompaso Barat memiliki dalam dada rata-rata 42,454 $\pm 4,148 \mathrm{~cm}$ dengan Koefisien keragaman 9,77\% dan rata-rata dalam dada kuda di Nusantara Polo Club Bogor Jawa barat $42,863 \pm 4,852 \mathrm{~cm}$ dengan koefisien keragaman 11,31\% (Tabel 3). dalam dada rata-rata kuda di Kecamatan Tompaso Barat di bandingkan dalam dada rata-rata kuda di Nusantara Polo Club Bogor Jawa barat tidak berbeda nyata. Pada Tabel 3 dalam dada rata-rata pada jantan maupun betina kedua daerah tidak berbeda nyata $(\mathrm{P}>0,05)$.

Dalam dada kuda di Kecamatan Tompaso Barat dan di Nusantara Polo Club Bogor Jawa Barat tidak berbeda nyata kemungkinan ada kesamaan genetik. Fourie et al. (2002) menyatakan bentuk dan ukuran tubuh dapat ditentukan dengan cara mengukur langsung ataupun secara visual.

\section{Tinggi Pundak}

Hasil pengukuran kuda di Kecamatan Tompaso Barat memiliki tinggi pundak rata-rata $149,545 \pm 5,040 \mathrm{~cm}$ dengan Koefisien keragaman 3,37 \% dan rata-rata tinggi pundak kuda di Nusantara Polo Club Bogor Jawa barat 155,363 \pm $5,150 \mathrm{~cm}$ dengan koefisien keragaman 3,31 $\%$ (Tabel 4). Tinggi pundak rata-rata kuda di Kecamatan Tompaso Barat di bandingkan tinggi pundak rata-rata kuda di Nusantara Polo Club Bogor Jawa barat berbeda sangat nyata .Pada Tabel 4 tinggi pundak rata-rata pada jantan kedua daerah berbeda nyata $(\mathrm{P}<0,05)$ dan tinggi pundak rata-rata pada betina kedua daerah berbeda sangat nyata $(\mathrm{P}<0,01)$. Tinggi pundak kuda di Kecamatan Tompaso Barat lebih pendek dibandingkan dengan kuda di Nusantara Polo Club Bogor Jawa Barat di karenakan kuda di Kecamatan Tompaso Barat mempunyai keturunan kuda lokal.

Kategori umum tinggi pundak menurut Sasimowski (1987) adalah ukuran 
Tabel 4. Rataan dan Varian Tinggi Pundak Kuda di Kecamatan Tompaso Barat dan di Nusantara Polo Club Bogor Jawa Barat.

\begin{tabular}{lllllll}
\hline \multirow{2}{*}{ No } & Jenis kelamin & \multicolumn{2}{c}{$\begin{array}{c}\text { Kecamatan Tompaso } \\
\text { Barat }\end{array}$} & $\begin{array}{l}\text { Nusantara Polo } \\
\text { Club }\end{array}$ & Hasil \\
\cline { 3 - 6 } & $\begin{array}{l}\text { Rata-rata }(\mathrm{Cm}) \\
\pm \text { SD }\end{array}$ & KK\% & $\begin{array}{l}\text { Rata- rata }(\mathrm{Cm}) \\
\pm \text { SD }\end{array}$ & KK\% & Uji t \\
\hline 1 & Jantan dan Betina & $149,545 \pm 5,040$ & 3,37 & $155,363 \pm 5,150$ & 3,31 & $* *$ \\
& $(\mathrm{n}=22)$ & & & & \\
2 & Jantan $(\mathrm{n}=9)$ & $152,222 \pm 2,948$ & 1,94 & $156,444 \pm 4,447$ & 2,84 & $*$ \\
3 & Betina $(\mathrm{n}=13)$ & $147,692 \pm 5,437$ & 3,68 & $154,615 \pm 5,635$ & 3,64 & $* *$ \\
\hline
\end{tabular}

**) Berbeda sangat nyata $(\mathrm{P}<0,01)$

*) Berbeda nyata $(\mathrm{P}<0,05)$

Ns) Tidak berbeda nyata/ non signifikan $(\mathrm{P}>0,05)$

pundak kurang dari $130 \mathrm{~cm}$ termasuk ke dalam kategori sangat kecil, 131 sampai $147 \mathrm{~cm}$ kecil, 148 sampai $158 \mathrm{~cm}$ sedang, 159 sampai $169 \mathrm{~cm}$ besar, lebih dari $170 \mathrm{~cm}$ sangat besar. Rataan tinggi pundak kuda di Kecamatan Tompaso Barat 149,545 \pm $5,040 \mathrm{~cm}$ dan di Nusantara Polo Club Bogor jawa barat 155,363 $\pm 5,150 \mathrm{~cm}$, jika dimasukan ke dalam kategori umum tinggi pundak maka Kuda di Kecamatan Tompaso Barat dan di Nusantara Polo Club Bogor Jawa Barat termasuk ke dalam kategori sedang. Kuda yang memiliki panjang badan dan tinggi pundak yang panjang mempunyai ruang langkah kaki yang luas yang menjadikan kuda dapat belari dengan cepat. Menurut Bruin et al. (1994) dan Van Weeren (1992) pengaruh lingkungan permanen pada performa berlari kuda adalah faktor nutrisi, cidera, pemilik, dan pelatih.

\section{Tinggi Pinggul}

Hasil pengukuran kuda di Kecamatan Tompaso Barat tinggi pinggul rata-rata $150,636 \pm 4,726 \mathrm{~cm}$ dengan Koefisien keragaman 3,13\% dan rata-rata tinggi pinggul kuda di Nusantara Polo Club Bogor Jawa barat $152,818 \pm 4,283 \mathrm{~cm}$ dengan koefisien keragaman 2,80\% (Tabel 5). tinggi pinggul rata-rata kuda di Kecamatan Tompaso Barat di bandingkan tinggi pinggul rata-rata kuda di Nusantara Polo Club Bogor Jawa barat tidak berbeda nyata. Pada Tabel 5 tinggi pinggul rata-rata pada jantan maupun betina kedua daerah tidak berbeda nyata $(\mathrm{P}>0,05)$.

Tinggi pinggul kuda di Kecamatan Tompaso Barat dan di Nusantara Polo Club Bogor Jawa Barat tidak berbeda nyata, ukuran tinggi pinggul yang cenderung sama dengan tinggi pundak menjelaskan secara proposional tubuh kuda berbentuk datar persegi saat berdiri yang mencirikan fungsi sebagai ternak tunggang. Kesamaan ukuran tubuh juga pernah dilaporkan pada 
Tabel 5. Rataan dan Varian Tinggi Pinggul Kuda di Kecamatan Tompaso Barat dan di Nusantara Polo Club Bogor Jawa Barat.

\begin{tabular}{|c|c|c|c|c|c|c|}
\hline \multirow[t]{2}{*}{ No } & \multirow[t]{2}{*}{ Jenis kelamin } & \multicolumn{2}{|c|}{$\begin{array}{c}\text { Kecamatan Tompaso } \\
\text { Barat }\end{array}$} & \multicolumn{2}{|l|}{$\begin{array}{c}\text { Nusantara Polo } \\
\text { Club } \\
\end{array}$} & \multirow{2}{*}{$\begin{array}{l}\text { Hasil } \\
\text { Uji t }\end{array}$} \\
\hline & & $\begin{array}{l}\text { Rata-rata }(\mathrm{Cm}) \\
\pm \mathrm{SD}\end{array}$ & $\mathrm{KK} \%$ & $\begin{array}{l}\text { Rata- rata }(\mathrm{Cm}) \\
\pm \mathrm{SD}\end{array}$ & $\mathrm{KK} \%$ & \\
\hline 1 & $\begin{array}{l}\text { Jantan dan } \\
\text { Betina }(n=22)\end{array}$ & $150,636 \pm 4,726$ & 3,14 & $152,818 \pm 4,283$ & 2,80 & $N s$ \\
\hline 2 & Jantan $(\mathrm{n}=9)$ & $152,889 \pm 2,472$ & 1,62 & $154,333 \pm 4,582$ & 2,97 & $N s$ \\
\hline 3 & Betina $(n=13)$ & $149,077 \pm 5,345$ & 3,58 & $151,769 \pm 3,897$ & 2,57 & $N s$ \\
\hline
\end{tabular}

bangsa ternak besar lainnya seperti ternak sapi (Gilbert at al, 1993).

\section{Lebar Pinggul}

Hasil pengukuran kuda di Kecamatan Tompaso Barat memiliki lebar pinggul rata-rata $38,954 \pm 1,963 \mathrm{~cm}$ dengan Koefisien keragaman 5,03\% dan rata-rata lebar pinggul kuda di Nusantara Polo Club Bogor Jawa barat 36,681 $\pm 3,197 \mathrm{~cm}$ dengan koefisien keragaman 8,71\% (Tabel 6). lebar pinggul rata-rata kuda di
Kecamatan Tompaso Barat di bandingkan lebar pinggul rata-rata kuda di Nusantara Polo Club Bogor Jawa barat berbeda sangat nyata. Pada Tabel 6 lebar pinggul rata-rata pada jantan maupun betina kedua daerah berbeda nyata $(\mathrm{P}<0,05)$. Data Tabel 6 menunjukkan bahwa sifat lebar pinggul atau yang memiliki lebar pinggul yang paling bagus adalah betina karena pada perhitungan tabel di atas betina yang memiliki nilai pinggul yang paling lebar dibanding jantan.

Tabel 6. Rataan dan Varian Lebar Pinggul Kuda di Kecamatan Tompaso Barat dan di Nusantara Polo Club Bogor Jawa Barat.

\begin{tabular}{|c|c|c|c|c|c|c|}
\hline \multirow[t]{2}{*}{ No } & \multirow[t]{2}{*}{ Jenis kelamin } & \multicolumn{2}{|c|}{$\begin{array}{c}\text { Kecamatan Tompaso } \\
\text { Barat }\end{array}$} & \multicolumn{2}{|l|}{$\begin{array}{l}\text { Nusantara Polo } \\
\text { Club }\end{array}$} & \multirow{2}{*}{$\begin{array}{l}\text { Hasil } \\
\text { Uji t }\end{array}$} \\
\hline & & $\begin{array}{l}\text { Rata-rata } \\
(\mathrm{Cm}) \pm \mathrm{SD}\end{array}$ & $\begin{array}{l}\text { KK } \\
\%\end{array}$ & $\begin{array}{l}\text { Rata- rata } \\
(\mathrm{Cm}) \pm \mathrm{SD}\end{array}$ & $\begin{array}{l}\text { KK } \\
\%\end{array}$ & \\
\hline 1 & $\begin{array}{l}\text { Jantan dan Betina } \\
(\mathrm{n}=22)\end{array}$ & $38,954 \pm 1,963$ & 5,04 & $36,681 \pm 3,197$ & 8,71 & $* *$ \\
\hline 2 & Jantan $(n=9)$ & $38,444 \pm 2,068$ & 5,38 & $35,777 \pm 3,734$ & 10,44 & $*$ \\
\hline 3 & Betina $(n=13)$ & $39,307 \pm 3,560$ & 4,80 & $37,307 \pm 2,750$ & 7,37 & $*$ \\
\hline
\end{tabular}


Tabel 7. Rataan dan Varian Panjang Badan Kuda di Kecamatan Tompaso Barat dan di Nusantara Polo Club Bogor Jawa Barat.

\begin{tabular}{|c|c|c|c|c|c|c|}
\hline \multirow[t]{2}{*}{ No } & \multirow[t]{2}{*}{ Jenis kelamin } & \multicolumn{2}{|c|}{$\begin{array}{c}\text { Kecamatan Tompaso } \\
\text { Barat }\end{array}$} & \multicolumn{2}{|l|}{$\begin{array}{l}\text { Nusantara Polo } \\
\text { Club }\end{array}$} & \multirow[b]{2}{*}{$\begin{array}{l}\text { Hasil } \\
\text { uji t }\end{array}$} \\
\hline & & $\begin{array}{l}\text { Rata-rata }(\mathrm{Cm}) \\
\pm \mathrm{SD}\end{array}$ & $\begin{array}{l}\mathrm{KK} \\
\%\end{array}$ & $\begin{array}{l}\text { Rata- rata }(\mathrm{Cm}) \\
\pm \mathrm{SD}\end{array}$ & KK\% & \\
\hline 1 & $\begin{array}{l}\text { Jantan dan Betina } \\
(\mathrm{n}=22)\end{array}$ & $146 \pm 3,464$ & 2,37 & $150,363 \pm 4,530$ & 4,53 & $* *$ \\
\hline 2 & Jantan $(n=9)$ & $146,667 \pm 4,301$ & 2,93 & $151,333 \pm 4,847$ & 3,20 & $*$ \\
\hline 3 & Betina $(n=13)$ & $145,538 \pm 2,846$ & 1,69 & $149,692 \pm 4,366$ & 2,92 & $* *$ \\
\hline
\end{tabular}

\section{Panjang badan}

Hasil pengukuran kuda di Kecamatan Tompaso Barat panjang badan rata-rata $146 \pm 3,464 \mathrm{~cm}$ dengan Koefisien keragaman 2,37 \% dan rata-rata panjang badan kuda di Nusantara Polo Club Bogor Jawa barat $150,363 \pm 4,530 \mathrm{~cm}$ dengan koefisien keragaman 3,01 \% (Tabel 7). panjang badan rata-rata kuda di Kecamatan Tompaso Barat di bandingkan panjang badan rata-rata kuda di Nusantara Polo Club Bogor Jawa barat berbeda sangat nyata. Pada Tabel 7 panjang badan rata-rata pada jantan kedua daerah berbeda nyata ( $P$ $<0,05)$ dan panjang badan rata-rata pada betina kedua daerah berbeda sangat nyata $(\mathrm{P}<0,01)$.

Panjang badan kuda di Kecamatan Tompaso Barat dan di Nusantara Polo Club Bogor Jawa Barat berbeda sangat nyata kemungkinan faktor perbedaan panjang badan di pengaruhi oleh genetik, lingkungan dan pakan yang diberikan.
Panjang badan pada umumnya memiliki nilai yang lebih kecil dibandingkan dengan nilai tinggi pundak (Wiradikusumah, 2016).

\section{Panjang Leher}

Hasil pengukuran kuda di Kecamatan Tompaso Barat panjang leher rata-rata 49,090 $\pm 4,139 \mathrm{~cm}$ dengan Koefisien keragaman $8,43 \%$ dan rata-rata panjang leher kuda di Nusantara Polo Club Bogor Jawa barat 56,590 $\pm 5,359 \mathrm{~cm}$ dengan koefisien keragaman 9,46\% (Tabel 8). panjang leher rata-rata kuda di Kecamatan Tompaso Barat di bandingkan panjang leher rata-rata kuda di Nusantara Polo Club Bogor Jawa barat berbeda sangat nyata. Pada Tabel 8 panjang leher rata-rata pada jantan maupun betina kedua daerah berbeda sangat nyata $(\mathrm{P}<0,01)$.

Panjang leher kuda di Kecamatan Tompaso Barat dan di Nusantara Polo Club Bogor Jawa Barat sangat berbeda nyata 
Tabel 8. Rataan dan Varian Panjang Leher Kuda di Kecamatan Tompaso Barat dan di Nusantara Polo Club Bogor Jawa Barat.

\begin{tabular}{llccccc}
\hline \multirow{2}{*}{ No } & Jenis kelamin & \multicolumn{2}{c}{$\begin{array}{c}\text { Kecamatan Tompaso } \\
\text { Barat }\end{array}$} & $\begin{array}{l}\text { Nusantara Polo } \\
\text { Club }\end{array}$ & Hasil \\
\cline { 3 - 6 } & $\begin{array}{l}\text { Rata-rata }(\mathrm{Cm}) \\
\pm \text { SD }\end{array}$ & KK\% & $\begin{array}{l}\text { Rata- rata }(\mathrm{Cm}) \\
\pm \text { SD }\end{array}$ & KK\% & Uji t \\
\hline 1 & $\begin{array}{l}\text { Jantan dan Betina } \\
(\mathrm{n}=22)\end{array}$ & $49,090 \pm 4,139$ & 8,43 & $56,590 \pm 5,359$ & 9,46 & $* *$ \\
2 & Jantan (n=9) & $48,777 \pm 4,409$ & 9,04 & $58,777 \pm 4,286$ & 7,29 & $* *$ \\
3 & Betina (n=13) & $49,307 \pm 4,110$ & 8,33 & $55,076 \pm 5,057$ & 9,18 & $* *$ \\
\hline
\end{tabular}

**) Berbeda sangat nyata $(\mathrm{P}<0,01)$;

*) Berbeda nyata $(\mathrm{P}<0,05)$

Ns) Tidak berbeda nyata/ non signifikan $(\mathrm{P}>0,05)$

kemungkinan ada perbedaan genetik. Dyce (2002), menambahkan bahwa proporsi yang baik antara kepala dan tubuh (badan serta leher) untuk seekor kuda pacu adalah sebesar 10\%-11\%: 89\%-90\%.

\section{Lebar Kepala}

Hasil pengukuran kuda di Kecamatan Tompaso Barat lebar kepala rata-rata $21,227 \pm 1,998 \mathrm{~cm}$ dengan Koefisien keragaman 9,41\% dan rata-rata lebar kepala kuda di Nusantara Polo Club
Bogor Jawa barat 19,363 $\pm 1,328 \mathrm{~cm}$ dengan koefisien keragaman 6,85\% (Tabel 9). lebar kepala rata-rata kuda di Kecamatan Tompaso Barat di bandingkan lebar kepala rata-rata kuda di Nusantara Polo Club Bogor Jawa barat berbeda sangat nyata. Pada Tabel 9 lebar kepala rata-rata pada jantan maupun betina kedua daerah berbeda nyata $(\mathrm{P}<0,05)$.

Lebar kepala kuda di Kecamatan Tompaso Barat dan di Nusantara Polo Club Bogor Jawa Barat sangat berbeda nyata

Tabel 9. Rataan dan Varian Lebar Kepala Kuda di Kecamatan Tompaso Barat dan di Nusantara Polo Club Bogor Jawa Barat.

\begin{tabular}{|c|c|c|c|c|c|c|}
\hline \multirow[t]{2}{*}{ No } & \multirow[t]{2}{*}{ Jenis kelamin } & \multicolumn{2}{|c|}{$\begin{array}{c}\text { Kecamatan Tompaso } \\
\text { Barat }\end{array}$} & \multicolumn{2}{|l|}{$\begin{array}{c}\text { Nusantara Polo } \\
\text { Club }\end{array}$} & \multirow{2}{*}{$\begin{array}{l}\text { Hasil } \\
\text { Uji t }\end{array}$} \\
\hline & & $\begin{array}{l}\text { Rata-rata } \\
(\mathrm{Cm}) \pm \mathrm{SD}\end{array}$ & $\mathrm{KK} \%$ & $\begin{array}{l}\text { Rata- rata } \\
(\mathrm{Cm}) \pm \mathrm{SD}\end{array}$ & $\mathrm{KK} \%$ & \\
\hline 1 & $\begin{array}{l}\text { Jantan dan Betina } \\
(\mathrm{n}=22)\end{array}$ & $21,227 \pm 1,998$ & 9,41 & $19,363 \pm 1,328$ & 6,85 & $* *$ \\
\hline 2 & Jantan $(n=9)$ & $21,888 \pm 2,315$ & 10,58 & $19,444 \pm 1,333$ & 6,85 & $*$ \\
\hline 3 & Betina $(n=13)$ & $20,769 \pm 1,690$ & 8,14 & $19,307 \pm 1,377$ & 7,13 & $*$ \\
\hline
\end{tabular}

**) Berbeda sangat nyata $(\mathrm{P}<0,01)$;

*) Berbeda nyata $(\mathrm{P}<0,05)$

Ns) Tidak berbeda nyata/ non signifikan $(\mathrm{P}>0,05)$ 
Tabel 10. Rataan dan Varian Panjang Kepala Kuda di Kecamatan Tompaso Barat dan di Nusantara Polo Club Bogor Jawa Barat.

\begin{tabular}{|c|c|c|c|c|c|c|}
\hline \multirow[t]{2}{*}{ No } & \multirow[t]{2}{*}{ Jenis kelamin } & \multicolumn{2}{|c|}{$\begin{array}{c}\text { Kecamatan Tompaso } \\
\text { Barat }\end{array}$} & \multicolumn{2}{|l|}{$\begin{array}{c}\text { Nusantara Polo } \\
\text { Club }\end{array}$} & \multirow{2}{*}{$\begin{array}{l}\text { Hasil } \\
\text { Uji t }\end{array}$} \\
\hline & & $\begin{array}{l}\text { Rata-rata } \\
(\mathrm{Cm}) \pm \mathrm{SD}\end{array}$ & $\begin{array}{l}\mathrm{KK} \\
\%\end{array}$ & $\begin{array}{l}\text { Rata- rata }(\mathrm{Cm}) \\
\pm \mathrm{SD}\end{array}$ & $\mathrm{KK} \%$ & \\
\hline 1 & $\begin{array}{l}\text { Jantan dan Betina } \\
(\mathrm{n}=22)\end{array}$ & $60,954 \pm 1,785$ & 2,92 & $59,863 \pm 2,273$ & 3,79 & $*$ \\
\hline 2 & $\operatorname{Jantan}(\mathrm{n}=9)$ & $61,333 \pm 1,118$ & 1,82 & $61,111 \pm 2,088$ & 3,41 & $N s$ \\
\hline 3 & Betina $(n=13)$ & $60,692 \pm 2,136$ & 3,52 & $59 \pm 2,041$ & 3,45 & $*$ \\
\hline
\end{tabular}

**) Berbeda sangat nyata $(\mathrm{P}<0,01)$

*) Berbeda nyata $(\mathrm{P}<0,05)$

Ns) Tidak berbeda nyata/ non signifikan $(\mathrm{P}>0,05)$

kemungkinan ada perbedaan genetik. Ensminger (1962) menyatakan bahwa kepala kuda yang baik memiliki mata yang agak menonjol dan letaknya cukup terpisah satu sama lain, jarak antara dua mata yang lebar memudahkan kuda untuk melihat ke depan dan ke belakang tanpa harus memalingkan kepala (visual latitude).

\section{Panjang Kepala}

Hasil pengukuran kuda di Kecamatan Tompaso Barat panjang kepala rata-rata $60,954 \pm 1,785 \mathrm{~cm}$ dengan Koefisien keragaman 2,92 \% dan rata-rata panjang kepala kuda di Nusantara Polo Club Bogor Jawa barat 59,863 $\pm 2,273 \mathrm{~cm}$ dengan koefisien keragaman 3,79\% (Tabel 10). panjang kepala rata-rata kuda di Kecamatan Tompaso Barat di bandingkan panjang kepala rata-rata kuda di Nusantara Polo Club Bogor Jawa barat berbeda nyata. Pada Tabel 10 panjang kepala rata-rata pada jantan kedua daerah tidak berbeda nyata $(\mathrm{P}>0,05)$ dan panjang kepala ratarata pada betina kedua daerah berbeda nyata $(\mathrm{P}<0,05)$.

Panjang kepala kuda di Kecamatan Tompaso Barat dan di Nusantara Polo Club Bogor Jawa Barat sangat berbeda nyata kemungkinan ada perbedaan genetik. Kepala kuda merupakan bagian tubuh yang menunjukkan karakteristik tertentu sesuai dengan jenis spesies, bangsa, jenis kelamin, habitat hidup dan kondisi kesehatan yang terlihat. Kuda yang hidup di daerah pegunungan dan dataran tinggi memiliki kepala yang relatif pendek dengan dahi yang lebih lebar dan panjang serta mempunyai moncong pendek (Sasimowski, 1987).

\section{KESIMPULAN}

Morfometrik kuda di Kecamatan Tompaso Barat cenderung lebih besar pada lebar Pinggul, lebar kepala dan panjang 
kepala dibanding kuda di Nusantara Polo

Club Bogor Jawa Barat. Namum

Morfometrik kuda di Nusantara Polo Club

Bogor Jawa Barat cenderung lebih besar pada lingkar dada, tinggi pundak, panjang badan dan panjang leher dibanding kuda di Kecamatan Tompaso Barat.

\section{DAFTAR PUSTAKA}

Bruin, G., H. Kuipers, H.A. Keizwe, G.J. Vander Vusse. 1994. Adaptation and overtraining in horses subjected to in creasing training loads. J Appl Physiol 6:1908-1913.

Dyce, K. M., W. O. Sack, and C. J. G. Wensing. 2002. Text Book of Veterinary Anatomy. Saunders Publishing, Pennsylvania.

Ensminger, M, E. 1962. Animal Science. Animal Agriculture Series. 5th Edit.Printers \& Publishers, Inc. Danville, Illinois.

Evan, P.D., S. Badianti, Nena. 2016. Hubungan Lingkar Dada dan Lebar Dada dengan Kecepatan Lari Kuda Sumba di Pacuan Kuda Tradisional. Fakultas Peternakan, Universitas Padjadjaran. Bandung. Students eJournal,Vol 5, No 2.

Fourie, P. J., F. W. C. Neser, J. J. Oliver dan C. V. D. Weathuizen. 2002. Relationshop between production performance, visual appraisal and body measurements or young Dorper Rams. South African J. of Anim. Sci 32 : 256 -262.

Gilbert, R.P., D.R.C. Bailey and N.H Shannon. 1993. Linear body measurements of cattle before and after 20 years of selection for postweaning gain when fed two different diet. J Anim Sci 71:17121720

Sasimowski, E., N. Moore. 1987. Animal Breeding and Production an Outline. Elsevier Science Publishing. USA.

Van Weeren, P.R., M.O. Jansen, A.J. Van Den Bogert, and A. Barneveld. 1992. A kinematic and strain gauge study of the reciprocal apparatus in the equine hindlimb. J. Biomech. 25:1291-1301. Dalam jurnal Hoyt et al 2002 Effect of trotting speed, load and incline on hindlimb stancephase kinematics.

Wiradikusumah, R.G., D. Rahmat, J.A. Siwi. 2016. Hubungan antara tinggi pundak dan panjang badan dengan kecepatan lari Gallop Kuda Polo Di Nusantara Polo Club Kecamatan Cibinong Kabupaten Bogor. Fakultas Peternakan, Universitas Padjadjaran. Bandung. Students eJournal 5(4):

Wood, C. dan S. Jackson. 2004. Horse Judging Manual. Kentucky Cooperative Exxtension. University of Kentucky 